\title{
Yatarak Tedavi Gerektiren Akut İshalli Çocukların Rotavirüs ve Enterik Adenovirüs Enfeksiyonu Yönünden Değerlendirilmesi
}

\author{
An Evaluation in Terms of Rotavirus and Enteric Adenovirus \\ Infection in Children With Acute Diarrhea Requiring in Patient
}

\section{Treatment}

\author{
Derya BAYIRLI TURAN ${ }^{1}$, Fatih KARAASLAN² ${ }^{2}$, Tuba KURUOĞLU³ ${ }^{3}$ KIvanç ŞEREFHANOĞLU
}

Iİstanbul Yeni Yüzyı Üniversitesi, Tıp Fakültesi Gaziosmanpaşa Hastanesi, Enfeksiyon Hastalıkları ve Klinik Mikrobiyoloji Anabilim Dalı, İstanbul,Türkiye

2̇̇stanbul Yeni Yüzyı Üniversitesi, Tıp Fakültesi Gaziosmanpaşa Hastanesi, Çocuk Sağlığı ve Hastalıkları Anabilim Dall, İstanbul,Türkiye ${ }^{3}$ Ondokuz Mayıs Üniversitesi Tıp Fakültesi, Enfeksiyon Hastalıkları ve Klinik Mikrobiyoloji Anabilim Dalı, Samsun,Türkiye

\section{ÖZ}

Amaç: Çocuklarda görülen akut ishallerde en sık viral etkenler rotavirüs ve enterik adenovirüstür. Her iki etkenin neden olduğu ishallerde çocukların klinik tablosu çok hızlı kötüleşebilmektedir. Kusma, dehidratasyon ve metabolik asidoz sonucu, hastalarda yatarak tedavi endikasyonu ortaya çıkmaktadır. Çalışmamızda yatarak tedavi gören enterik adenovirüs ve rotavirüs ishalli vakaları epidemiyolojik açıdan değerlendirerek demografik verilerini irdelemek ve hangi tedavilerin uygulandığını göstermeyi amaçladık.

Gereç ve Yöntemler: 1 Ocak 2016-31 Aralık 2017 tarihleri arasında ishal şikayeti ile başvuran 0-14 yaş aralığında 1281 çocuk hasta retrospektif olarak incelendi. Bu hastalar arasında akut gastroenterit tanılı, rotavirüs ve enterik adenovirüs antijen testi değerlendirimiş, gaita mikroskopisinde parazit olmayan ve gaita kültüründe Salmonella-Shigella spp üremesi olmayan ve hastanede en az 24 saat yatış süresi olan 443 hasta çalışma grubu olarak belirlendi. İstatistik metodu olarak T testi ve Ki kare testleri kullanıldı. Çalışmada $p<0,05$ değeri anlamlı olarak kabul edildi.

Bulgular: İshal şikayeti ile başvuran 1281 hastanın 443(\%34.6)'ü yatarak takip edildi. 38 (\%2.9) hastada enterik adenovirüs, 95(\%7.4) hastada ise rotavirüs antijeni testi pozitifti. Hastalarda ki en sık şikayetler sıklık sırasıyla bulantıkusma, halsizlik ve ateş olup, karın ağrısı en az saptanan şikayettir. Yatarak tedavi edilen hastalarda tek başına probiyotik kullanımı rotavirüs ishalli hastalarda \%61, enterik adenovirüs enfeksiyonlu hastalarda \%63.2 oranında en sık kullanılan ilaç grubu olmuştur. Antibakteriyel etkili antibiyotikler \%58 oranında rotavirüs ve enterik adenovirüs antijeni negatif ishalli hastalarda, en yüksek oranda kullanılan tedavi ajanıdır. Antiprotozoal etkili antibiyotikler, rotavirüs antijeni ve enterik adenovirüs antijeni pozitif grupta ve her iki etken için negatif hasta grubunda en az tercih edilen ilaçlardı.

Sonuç: Çocukluk çağı ishallerinde viral etkenler göz önünde bulundurulmalıdır. İshalin tedavisinde öncelikle kaybedilen sıvının yerine konması planlanmalıdır. Antibakteriyel ya da antiprotozoal antibiyoterapi için laboratuvar testleri yönlendirici olmalıdır. Hastanede yatarak tedavi gören ve viral etiyoloji düşünülen ishalli çocuk hastalara rotavirüs ve enterik adenovirüs antijeni hızlı tanı testleri kullanılarak erken tanı konulabileceği, böylece semptomatik tedaviler ile gereksiz antibiyotik kullanımın önüne geçilebileceği değerlendirilmiştir.

Anahtar Sözcükler: Akut viral ishal, Adenovirüs, Hastaneye yatış, Rotavirüs

\begin{abstract}
Objective: The most common viral agents causing acute diarrhea in children are rotavirus and enteric adenovirus, respectively. In diarrhea cases caused by these both factors, the clinical manifestation of children can deteriorate very rapidly. Vomiting, dehydration, and metabolic acidosis seen especially in children cause indications for receiving inpatient treatment. In this study, we aimed to evaluate the epidemiologic aspects of enteric adenovirus and rotavirus diarrhea cases in the inpatients treated in our hospital, to analyze the demographic data, and to show what treatments were applied.
\end{abstract}

\section{(i) \\ BAYIRLI TURAN D : 0000-0002-7505-341X KARAARSLAN F : 0000-0002-3299-5853 KURUOĞLU T: :0000-0003-3805-367X ȘEREFHANOĞLU Ș :0000-0003-0585-8797}

Çıkar Çatışması / Conflict of Interest: On behalf of all authors, the corresponding author states that there is no conflict of interest.

Etik Kurul Onay / Ethics Committee Approval : Bu çalıșma için Akademik Kurul onayı alınmıștır.

Yazarların Katkısı / Contribution of the Authors: BAYIRLI TURAN D: Çalıșmanın fikrinin olușturulması ve her așamada çalışmaya ait tüm kontrollerin yapılması, makalenin yazımı. KARAARSLAN F: Verilerin toplanması, analizi ve makalenin yazımı, KURUOĞLU T: Verilerin toplanması, analizi ve makalenin yazımı ŞEREFHANOĞLU Ş: Her aşamada çalıșmaya ait tüm kontrollerin yapılması

Atıf yazım șekli / How to cite: Bayırlı Turan D, Karaarslan F, Kuruoğlu T, Șerefhanoğlu Ș.Yatarak Tedavi Gerektiren Akut İshalli Çocukların Rotavirüs ve Enterik Adenovirüs Enfeksiyonu Yönünden Değerlendirilmesi. Turkish J Pediatr Dis 2020; 14: $220-224$.
Yazışma Adresi / Correspondence Address:

Derya BAYIRLI TURAN

İstanbul Yeni Yüzyıl Üniversitesi Tıp Fakültesi Gaziosmanpaşa Hastanesi

Enfeksiyon Hastalıkları ve Klinik Mikrobiyoloji Anabilim Dalı,İstanbul, Türkiye

E-posta: deryabturan@gmail.com
Geliș tarihi / Received : 13.08.2019 Kabul tarihi / Accepted : 28.01.2019 Elektronik yayın tarihi : :28.05.2019 Online published

DOI: $10.12956 /$ tchd.506721 
Material and Methods: Data of a total of 1281 pediatric patients between 0 and 14 years old admitted to Yeni Yüzyll University Medical Faculty Gaziosmanpaşa Hospital between 1 January 2016- 31 December 2017 due to diarrhea were evaluated retrospectively. The study group consisted of acute-gastroenteritis-prediagnosed 443 patients with no parasites on stool microscopy and without any SalmonellaShigella spp. growth in the stool culture. These patients had also test results of rotavirus and enteric adenovirus antigens, and stayed at hospital for at least 24 hours. Pearson's chi-square test and t test were used for statistical analysis, and p<0.05 was considered significant.

Results: A total of 443 (34.6\%) of the 1281 patients with diarrhea were hospitalized. Thirty-eight (2.9\%) patients had a positive enteric adenovirus test, and 95 (7.4\%) had rotavirus. The most common complaints were nausea, vomiting, fatigue, and fever. Abdominal pain was the least common complaint. Probiotic use alone was $61 \%$ in patients with rotavirus diarrhea, and $63.2 \%$ in patients with enteric adenovirus infection. Antimicrobial antibiotics were used in 58\% of patients with negative rotavirus and enteric adenovirus antigens. Antiprotozoal-effective antibiotics were the least preferred drugs in the patients with either positive or negative test results for rotavirus and enteric adenovirus antigens.

Conclusion: Viral factors should be considered in childhood diarrhea. In the treatment of diarrhea, the replacement of the lost fluid should be planned primarily. Laboratory tests for antibacterial or antiprotozoal antibiotics should be taken into consideration. Early diagnosis of rotavirus and enteric adenovirus antigens can be made using rapid diagnostic tests in the hospitalized pediatric patients with diarrhea. Thus, we consider that unnecessary antibiotic use can be prevented by symptomatic treatments in these patients.

Key Words: Acute viral diarrhea, Adenovirus, Admission to the hospital, Rotavirus

\section{GiRiş}

İshal dünya genelinde, sağlık kuruluşlarına en sık başvuru nedenleri arasındadır. Çocuklar bu hastalıktan en çok etkilenen yaş grubudur. Viral etkenler en sık görülen enfeksiyöz gastroenterit etkenlerindendir. Çocuklarda en sık görülen viral gastroenterit etkenleri rotavirüs ve enterik adenovirüstür $(1,2)$. Her ikisi de zarfsız yapıya sahip, sabun ve pek çok dezenfektana karşı dirençlidirler. Fekal-oral yol ve ortak kullanılan eşyalar kişiden kişiye kolayca bulaşmalarına neden olmaktadır (3). İshal nedeniyle hastaneye yatan çocukların yarıdan fazlasında etken rotavirüstür. Rotavirüs ishallerinde üç ila sekiz gün sürebilen ateş, kusma, diyare, abdominal kramp ve miyalji sık görülen semptomlardır. Kusma ile birlikte olan diyare dehidratasyon gelişmesine, oral yolla beslenememe dehidratasyonun hızla derinleşmesine, sonuç olarak da klinik tablonun kısa sürede kötüleşmesine neden olur. Bu durum hastanede yatarak parenteral SIVı replasmanı tedavisini gerektirebilmektedir $(4,5)$. Enterik adenovirüs ishalleri ise ikinci sıklıkta hastaneye yatış gerektiren uzun süren ishallere neden olmaktadır. Bu ishal türünde kusma ve ateş hafif seyirlidir (6). Her iki viral etken de epidemiyolojik, ekonomik sorunları da beraber getiren halk sağlığı problemidir (1).

Rotavirüs beş yaş altı çocuklarda her yıl iki milyon çocuğun hastaneye yatmasına neden olmaktadır $(1,5)$. Özellikle bu yaş grubu çocuklarda gelişen kusma, dehidratasyon ve metabolik asidoz sonucu ise her yıl dünyada iki milyon hastaneye yatış, 800 bin ölüm vakası görülmektedir (7). Bu ölümlerin çoğunun ülkemiz gibi gelişmekte olan ülkelerde olması dikkat çekicidir. Rotavirüs tüm dünyada endemiktir ve soğuk aylarda, soğuk iklimli bölgelerde daha çok görülmektedir (8). Ülkemizdeki sıklığı \%9.8-50 arasında bildirilmektedir (2,9). Enterik adenovirüs gastroenteritleri ise daha çok sıcak iklimde özellikle iki yaş üzeri çocuklarda, kamp ortamlarında, belli coğrafik bölgelerde olmak üzere sporadik vakalar olarak karşımıza çıkmaktadır. Özellikle enterik adenovirüs tip 40 ve 41 dünyanın her bölgesinde yaygın olarak görülmektedir (2). Ülkemizdeki sıklığının \%7.8-10 olarak değiştiğini bildiren çalışmalar bulunmaktadır (9-11).
Viral etiyoloji düşünülen ishaller için hastalığın görüldüğü mevsim, hasta yaşı, gaitanın makroskopik ve mikroskopik bulguları klinisyenlere tanıda yardımcıdır. Enzyme-Linked Immuno Sorbent Assay (ELISA), lateks aglütinasyon ve hızlı immünokromotografik yöntemler gibi basit, hassas, kısa zamanda sonuç alınabilen, gaitadan antijen tespitine yönelik güvenilir testler ile ayırıcı tanı yapılabilir $(2,3)$.

Çalışmamızda hastanemizde yatarak tedavi gören enterik adenovirüs ve rotavirüs ishalli vakaları epidemiyolojik açıdan değerlendirerek demografik verilerini irdelemek ve hangi tedavilerin uygulandığını göstermeyi amaçladık.

\section{MATERYAL METOD}

\section{Çalışmanın kapsamı}

01 Ocak 2016-31 Aralık 2017 tarihleri arasında ishal şikayeti ile başvuran 0-14 yaş aralığında 1281 çocuk hasta çalışmaya alındı. Bu hastalardan akut gastroenterit tanısı alan, gaita numunelerinden rotavirüs ve enterik adenovirüs antijen hızlı immünokromotografik testi çalışılan, aynı gaita numunesinde yapılan mikroskopi incelemelerinde parazit trofozoit ve kisti görülmeyen ve gaita kültüründe Salmonella-Shigella spp üremesi olmayan ve öykülerinde ishal gelişiminden önce antibiyotik kullanımı bulunmayan hastalar retrospektif olarak değerlendirildi. Bu kriterleri taşıyan ve yatış süresi en az 24 saat olan 443 hasta çalışma grubu olarak belirlendi.

\section{Örnekler ve çalışma tekniği}

Hastalardan alınan numuneler bir saat içinde hızlı immünokromotografik test yöntemiyle (Rotavirüs antijen testi ve Rota/Adeno antijen testi, Standart Diagnostics Bioline, Korea) ile çalışıldı. Rotavirüs ve rotavirüs/enterik adenovirüs antijen test spesifiteleri \%100, \%97.4 ve sensiviteleri \%99.7, \%100'di.

\section{Hastaların klinik verileri ve özellikleri}

Demografik veriler, klinik bulgular ve uygulanan tedavi seçenekleri hastane bilgi yönetim sisteminden alındı. 
İstatistik: Çalışma verileri SPSS Versiyon 15.0 (Statistical Package for Social Sciences, IBM Company) ticari yaziımı ile değerlendirildi. İstatistik metod olarak $\mathrm{T}$ testi ve Ki kare testleri kullanıldı. Çalışmada $p<0,05$ değeri anlamlı olarak kabul edildi.

\section{BULGULAR}

İshal şikayeti ile başvuran 1281 çocuk hastanın 443 (\%34.6)'ü hastanemizde yatarak takip edildi. Hastaların 38 (\%2.9)'inde enterik adenovirüs ve 95 (\%7.4)'inde rotavirüs antijeni pozitifti. Rotavirüs antijeni pozitif hastalarda ortalama yaş 63 ay, enterik adenovirüs antijeni pozitif hastalarda ortalama yaș 62 aydı. Yatış yapılan hastaların rotavirüs antijeni pozitif grupta \%56.8'si ve enterik adenovirüs antijeni pozitif grupta \%65.7'si erkek çocuklardı. Tüm ishalli hastalarda en sık şikayetler sırasıyla bulantı-kusma, halsizlik ve ateş olup, karın ağrısı en az saptanan șikayetti. Tüm hastalar temas izolasyonuna alınarak dehidratasyon derecelerine göre parenteral SIVI tedavisi ile izlenmişti. Hastalara gerektiğinde semptomatik tedavi olarak bulantı için anti-emetik ve ateş yönetimi için parasetamol ve benzeri ilaçlar kullanımıştı. İshal tedavisi için probiyotik, çinko, antibakteriyel ve antiprotozoal etkili antibiyotikler kullanımıștı. Hastaların detaylı demografik verileri Tablo I'de verildi. Tek başına probiyotik kullanım oranı rotavirüs ishalli hastalarda $\% 61$, enterik adenovirüs enfeksiyonlu hastalarda \%63.2 en sık verilen ilaç grubu idi. Probiyotik olarak Saccharomyces boulardii içeren probiyotik uygulanmıştı. Antibakteriyel etkili antibiyotikler rotavirüs ve enterik adenovirüs antijeni negatif ishalli hastalarda \%58 oranında kullanılmıştı. Antiprotozoal etkili antibiyotiklerhem; rotavirüs antijeni ve enterik adenovirüs antijeni pozitif grupta hem de negatif hasta grubunda en az tercih edilen ilaçlardı. Antibakteriyel etkili antibiyotiklerden ampisilin, amoksisilin/yerine klavulanik asit, sefuroksim, sefiksim, seftriakson, sefotaksim ve trimetoprim-sulfometaksozol tercih edilmişken, antiprotozoal antibiyotiklerden metronidazol uygulanmıştı. Rotavirüs antijeni ve enterik adenovirüs antijeni pozitif hasta grupları ile negatif hasta grubu arasında yaş, semptomlar ve tedavi seçimleri açııından istatiksel anlamlı fark saptanmadı.

\section{TARTIŞMA}

Viral gastroenteritlerin en sık etkenlerinden olan rotavirüs ve enterik adenovirüs beș yaș altı hastalarda morbidite ile sonuçlanan gastroenteritlere neden olmaktadır $(2,12)$. Son yıllarda giderek artan bu enfeksiyonlar özellikle geri kalmış ve gelişmekte olan ülkelerdeki çocuklarda önemli halk sağığı sorunudur (12). Gelişmiş ülkelerde nadir de olsa görülen mortal vakaların \%86'sında etken rotavirüs iken gelişmekte olan ülkelerde bu oran \%50'nin üzerindedir (13). Çok sulu bir ishal ve şiddetli kusma ile kısa sürede hastaların derin bir dehidratasyona girmesine neden olmaktadır. Bu durum hastaların hastaneye yatarak tedavi almalarını gerektirmektedir (4).

Yatarak tedavi altına alınan ishal şikayetli hastaların \%21.4'ü rotavirüs, \%8.6'sı enterik adenovirüs antijeni pozitif hastalardı. Parashar ve ark.(14) 63 ülkede yaptıkları çalışmada diyare nedeniyle hastaneye yatan çocukların \%33-49'unun rotavirüs nedeniyle yatış yapıldığını bildirmişlerdir. Jaha ve ark.(13) çalışmasında ise ishal nedeniyle hastaneye yatırılarak tedavi alıına alınan çocukların \%34.4'ü, Nitsch-Osuch ve ark. (15) çalışmalarında ise \%24'ü rotavirüs enteriti tanısıyla yatış yapılan hastalardan oluştuğu raporlanmıştır. Avrupa'da yapılan ve birçok ülkeyi içine alan çalışmada ishalli çocuklarda rotavirüs pozitifliği \%27-52 olarak belirtilmiştir (16). Çalışmamızda saptadığımız oranın düşük olması, ülkemizin bulunduğu bölgesel ve sosyoekonomik koşullardan kaynaklandığını düşündürmektedir. Enterik adenovirüs kaynaklı ishallerin daha

Tablo I: Yatarak tedavi gören ishalli hastaların özellikleri.

\begin{tabular}{|c|c|c|c|c|}
\hline & $\begin{array}{l}\text { Rotavirüs pozitif } \\
\text { n=95 (\%21.4) }\end{array}$ & $\begin{array}{l}\text { Enterik adenovirüs pozitif } \\
\qquad \mathrm{n}=38(\% 8.6)\end{array}$ & $\begin{array}{c}\text { Rotavirüs ve enterik adenovirüs } \\
\text { negatif } \\
\mathrm{n}=310(\% 70)\end{array}$ & p \\
\hline Ortalama yaş/(ay) & 63 & 62 & 66 & 0.14 \\
\hline Kı/Erkek & $41 / 54$ & $13 / 25$ & $136 / 174$ & 0.226 \\
\hline \multicolumn{5}{|l|}{ Semptomlar } \\
\hline Ateş & $54(\% 56.8)$ & $14(\% 36.8)$ & $158(\% 50.9)$ & 0.054 \\
\hline Halsizlik & 66(\%69.5) & 25(\%65.8) & 204(\%65.8) & 0.685 \\
\hline Bulantı-kusma & $75(\% 78.9)$ & $25(\% 65.8)$ & 206(\%66.5) & 0.124 \\
\hline \multicolumn{5}{|l|}{ Tedavi } \\
\hline Probiyotik & $58(\% 61)$ & 24(\%63.2) & $131(\% 42.3)$ & 0.491 \\
\hline Antibakteriyel Antibiyotik & 40(\%42) & $11(\% 28.9)$ & $180(\% 58)$ & 0.173 \\
\hline \multirow{3}{*}{$\begin{array}{l}\text { Antiprotozoal Antibiyotik } \\
\text { Probiyotik + } \\
\text { Antibakteriyel Antibiyotik } \\
\text { Çinko }\end{array}$} & 5(\%5.2) & $3(\% 7.9)$ & $33(\% 10.6)$ & 0.688 \\
\hline & $25(\% 26.3)$ & $7(\% 18.4)$ & $85(\% 27.4)$ & 0.388 \\
\hline & $43(\% 45.2)$ & $16(\% 42.1)$ & $96(\% 30.9)$ & 0.352 \\
\hline
\end{tabular}


az sıklıkla olmak üzere \%4.8-20 oranında olduğu bildirilmektedir $(3,17)$. Wiegerin ve ark.(12) çalışmalarında ise diyare nedeniyle hastaneye yatan çocukların \%9.7'sinde enterik adenovirüs nedeniyle yatış yapıldığı belirtilmiştir. Yatarak tedavi altına alınan hastalarda enterik adenovirüs sıklığı ise literatürle uyumludur. Rota ve enterik adenovirüs ishal tanısı literatürle uyumlu olarak erkek cinsiyette daha sık görülmüştür $(15,17)$.

İshal nedeniyle hastaneye yatan hastaların pek çoğunda etiyoloji bilinmemektedir (17). Yine Smok ve ark. (1) çalsşmasında da ishal nedeniyle hastaneye yatırılan hastaların çoğunda ishale neden olan etken belli değilken ikinci sıklıkta rotavirüs ve enterik adenovirüsle karşılaştıklarını belirtmişlerdir. Benzer olarak çalışmamızda da hastalarımızın \%70' inde etiyoloji belirlenememiştir.

Rotavirüs ve enterik adenovirüs ishallerinin en sık görüldüğü yaş grubu beş yaş altı hastalardır (1,17-18). Çalışmamızda benzer olarak rotavirüs pozitif hastaların ortalama yaşı 63 ay ve enterik adenovirüs pozitif hastaların ortalama yaşı ise 62 aydı.

Rotavirüs enteritleri en sık kusma, diyare ve dehidratasyon bulguları ile beraberdir (12). Jaha ve ark. (13) yaptıkları çalışmada rotavirüs gastroenteritli çocukların \%88'inde kusma, \%43.9'unda ateș en sık bulgu olarak saptamışlardır. Nakanishi ve ark. (17) rotavirüs pozitif vakalarında ateş ve kusma ön plandayken, enterik adenovirüs pozitif ishal vakalarında diyare şikayeti ön plandaydı. Gürbüz ve ark.(9) yaptıkları çalışmada rotavirüsün neden olduğu ishallerin kliniğinin enterik adenovirüse göre daha şiddetli olduğunu raporlamışlardır. Çalışmamızda rotavirüs gastroenteritli hastalarda bulantı, halsizlik ve ateș şikayetleri enterik adenovirüs gastroenteritli hastalara oranla daha fazla saptanmıştır.

Her iki etken de kreş ve okullarda, ortak yaşamın olduğu koşullarda; ortak kullanilan tuvaletler, oyuncaklar ile sık bulaşmakta, su yolu ile bulaşan enfeksiyonlar küçük salgınlar şeklinde seyredebilmektedir. Hastaneye yatırlan hastalarda enfeksiyonun kontrolü ve diğer yatan hastalara bulaşın engellenmesi için temas izolasyonu uygulanmalıdır (5). Polonya'da yapılan bir çalışmada nozokomiyal rotavirüs enfeksiyonlu vakaların giderek artıı̆ından bahsedilmiștir (15). $\mathrm{Bu}$ durum rotavirüsün yakın temasla kolay bulaşabileceğini ve bu hastaların temas izolasyonuna alınması gerektirdiğini göstermektedir. Özellikle nozokomiyal salgınların önlenmesi için temas izolasyonun şart olduğu vurgulanmaktadır.

İshalin temel tedavisi kaybedilen sıvının ve elektrolitlerin yerine konmasıdır. İshal şiddetinin azaltılması tedaviye yardımcıdır. Yeterli oral alamayan çocukların ve gelişen dehidratasyonun durumuna göre hastaneye yatış ve kristaloid ağırlıklı sıvılar ile parenteral SIVI replasman tedavisi gerekmektedir (2). Çalıșmamızda rotavirüs antijeni pozitif çıkan ishalli hastaların \%42'sine, enterikadenovirüs antijeni pozitifhastaların \%28.9'una ve her iki etkenin negatif olduğu hasta grubunun \%58'ine antibiyotik başlandığı saptanmışıı. Viral etiyoloji düşünülmesine rağmen yüksek oranlarda antibiyotik kullanımasının tercih edilmesi, bu hastalar için doğru ve hızı tanı ile gereksiz antibiyotik kullanımının önüne geçebileceğini düşündürmüştür. Bilindiği gibi akut gastroenteritlerde antibiyotik endikasyonu sınırıdır. İshalin primer tedavisi sIVı desteğidir $(4,19)$. Rotavirüs ishallerinde ateşin enterik adenovirüse bağlı ishallere oranla daha fazla görülmesi rotavirüs antijeni pozitif grupta \%42 oranındaki yüksek antibiyotik kullanım tercihinin nedeni olabilir. İshal tedavisinde çocuklarda antibakteriyel antibiyotik olarak kinolon kullanımı yan etkileri sebebi ile tercih edilmemektedir. Ancak trimetoprim-sulfametaksazol ishal tedavisinde seçilebilecek temel ajanlardan biri olmasına rağmen bunun yerine başta üçüncü kuşak sefalosporinler olmak üzere betalaktam ajanların tercih edilmesi, kesinleştirilmiş veya muhtemel viral etiyoloji düșünülmesine rağmen antibiyotik kullanıması, ülkemizde akılcı antibiyotik kullanım ilkelerine uyumun halen yeterli seviyede olmadığını göstermesi bakımından önemlidir (5). Hastalarımızın \%52.1'ine antibiyotik bașlanması ve antibiyotik olarak üçüncü kuşak sefalosporinlerin tercih edilmesi bu bilgiyi desteklemektedir. Enterik adenovirüs için de hızı tanı yöntemlerinin kullanılması gereksiz antibiyotik kullanımını önleyecek ve uygun tedavi seçimine yardımcı olacaktır. Bu konuyla ilgili gerekli tedbirlerin alınması, güvenilir testlerle hızlıca ishal etkenlerinin ortaya konması uygun tedavi planlanması açısından önemlidir.

İshalli hastaların tedavisinde özellikle sosyo-ekonomik seviyesi düşük bölgelerde ishal şiddetinin azaltılması için çinko ve probiyotik tedavileri tercih edilmektedir (2). Avrupa ülkelerinde yapılan çalışmalarda, çinko tedavisi malnütrisyonu olan çocuklar için önerilmiştir. Probiyotiklerin ise ishalli hastaların tedavisinde kullanımı, enfeksiyöz ishalin süresini ve dışkı sıklığını azaltmakta yararlı etkileri ve güvenilir olduğu belirtilmiştir. Tüm bu nedenlerle, antibiyotik ishalleri dışında, probiyotiklerin rutin kullanımı değil, hastaya göre değerlendirilerek kullanımı daha doğru olacaktır (19). Çalışmamızda rotavirüs antijeni pozitif hastaların \%45.2'sine, enterik adenovirüs antijeni pozitif hastaların \%42.1'ine ve her iki etkenin negatif olduğu grupta \%30.9'una çinko süspansiyonu tedavisi tercih edilmiştir. Bu durumu hasta populasyonumuzun İstanbul'un düşük sosyo-ekonomik bölgelerinden olmasılyla açıklamaktayız. Tek başına probiyotik tercihi ise rotavirüs ishalli hastalarda \%61, enterik adenovirüs enfeksiyonlu hastalarda \%63.2 olarak benzer oranda en sık verilen ilaç grubuydu. Ayrıca probiyotikler antibakteriyel antibiyotikler ile kombine olarakta uygulanmıştı.

Hastalarımıza antiparaziter tedavi başlandığını da tespit ettik. Bu durumun muhtemel nedeni gaita mikroskopi tekniği ile Giardia intestinalis ve Entamoeba histolitica tanısında yetersiz kalınmasıdır. Çünkü tek mikroskopik değerlendirme ile protozoaların kist ve trofozoid tanısı konulamaması, ELISA yöntemi ile antijen tarama testlerini gerekli kılmaktadır.

Çalışmamızda ishal nedeniyle hastaneye yatırlarak tedavi altına alınan hastaların bir çoğunda etiyoloji bilinmemekle beraber rotavirüs ve enterik adenovirüs en sık izole edilen viral etkenlerdendir. Buna rağmen rotavirüs pozitif hastalara antibakteriyel ve antiprotozoal etkili antibiyotikler kullanımış olup 
enterik adenovirüs etkenli vakalarda antibakteriyel antibiyotikler daha çok tercih edilmiştir. Probiyotik tedavisi tek başına veya antibakteriyel antibiyotikler ile kombine başlanmıştır. İshalli hastaya yaklaşım yeniden gözden geçirilerek vakaların tanısı hızla konulduktan sonra, öncelikle kaybedilen sıvının yerine konması planlanmalıdır. Antibakteriyel ya da antiprotozoal antibiyoterapi için laboratuvar testleri yönlendirici olmalıdır.

Çalışmamızı kısıtlayan bir durum, hastaneye yatırılan hastalarda ishal etkeni olarak norovirüs araştırımamasıdır. Norovirüs ishallere neden olan ve sıklığı giderek artan diğer bir viral etken olup, hızlı immunokromotografik testi de bulunmaktadır $(3,4)$. Ancak Sağlık Uygulama Tebliği'nde geri ödeme karşılı̆ının olmaması ve bu etken konusunda farkındalığın az olması test isteminin az olmasının muhtemel sebebi olabilir.

Rotavirüs enfeksiyonundan korunmanın en önemli yolu çocukların aşılanmasıdır. Rotavirüs aşısı monovalan ve pentavalan olmak üzere iki farmasötik şekilde bulunmaktadır. Așılama yapılmasına rağmen, aşılı çocuklarda rotavirüs ishalleri görülebilir, ancak hastaneye yatış ve sıvı replasmanı gerektirecek dehidratasyon sık olmaz. Bu hastalar duyarlı çocuklara bulaştırıcılıkta rezervuar olarak önemlidir (5). Enterik adenovirüse karşı ise aşı bulunmamaktadır. Bu çalışmanın kısıtıı̆̆g retrospektif bir çalışma olması ve yetersiz klinik kayıtlar nedeni ile rotavirüs aşılama öyküsünün değerlendirilememiş olmasıdır.

Sonuç olarak; çocukluk çağı ishallerinde viral etkenler göz önünde bulundurulmalıdır. Hastanede yatarak tedavi gören viral etiyoloji düşünülen ishalli çocuk hastalarda gaitada rotavirüs ve enterik adenovirüs antijeni hızlı tanı testleri uygulanarak erken ayırıcı tanı yapılabileceği ve böylece semptomatik tedaviler verilerek gereksiz antibiyotik kullanımının önüne geçilebileceği değerlendirilmiştir.

\section{KAYNAKLAR}

1. Smok B, Zieniewicz-Cieślik K,Smukalska E, Pawłowska M. Acute diarrhoea induced by rotavirus in children hospitalysed in Provincial Hospital for Infectious Diseases in Bydgoszcz in 2014 year. Przegl Epidemiol 2016;70:462-70.

2. Kurugöl Z. Devrim I. Gastrointestinal Infections. J Pediatr Inf 2014;8:71-81.

3. Farkas $T$, Jiang X. Rotaviruses, caliciviruses, astroviruses, enteric adenoviruses and other diarrheic viruses. In: Murray PR, Baron EJ, Jorgensen JH, Landry ML, Pfaller MA eds. Manual of Clinical Microbiology. 9th ed. Washington: ASM Press, 2007

4. Bass CW, Dorsey $\mathrm{KN}$ : Rotavirus and other agents of viral gastroenteritis. In Nelson Textbook of Pediatrics Edited by: Richard E and Behrman F. Raven Press, Philadelphia, 2004

5. Crawford SE, Ramani S, Tate JE, Parashar UD, Svensson L, Hagbom M, Franco MA, Greenberg HB, O’Ryan M, Kang G, Desselberger $U$, Mary Kestes. Rotavirus infection. Nat Rev Dis 2018;9:3.

6. Ozdemir S, Delialioğlu N, Emekdaş G. Investigation of rotavirus, adenovirus and astrovirus frequencies in children with acute gastroenteritis and evaluation of epidemiological features. Mikrobiyol Bul 2010; 44: 571-8.
7. Junaid SA, Umeh C, Olabode AO, Banda JM. Incidence of rotavirus infection in children with gastroenteritis attending Jos university teaching hospital. Nigeria. Virol J 2011;8:233.

8. Salim H, Karyana IPG, Sanjaya-Putra IGN, Budiarsa S and Soenarto Y. Risk factors of rotavirus diarrhea in hospitalized children in Sanglah Hospital, Denpasar: a prospective cohort study. BMC Gastroenterology 2014;14:54.

9. Gürbüz F, Tezer H, Şaylı TR. Etiologic factors and Clinical findings of patients hospitalized chidren for acut gastroenteritis epidemiologic study. Turkish J Pediatr Dis 2010;4:211-8.

10. Ozdemir S, Delialioğlu N, Emekdaş G. Investigation of rotavirus, adenovirus and astrovirus frequencies in children with acute gastroenteritis and evaluation of epidemiological features. Mikrobiyol Bul 2010;44:571-8.

11. Altındiş M, Beştepe G, Çeri A. Akut ishal yakınmalı çocuklarda rotavirüs ve enterik adenovirüs sıklı̆ı̆ araştırma. SDÜ Tıp Fak Derg 2008:15:17-20.

12. Wiegering V,Kaiser J,Tappe D,Weissbrich B,Morbach H,Girschick HJ. Gastroenteritis in childhood a retrospective study of 650 hospitalized. Int J Infect Dis 2011;15:e401-7.

13. Jaha VI, Shala M, Azemi M, Hoxa-Kanberi T, Avdiu M, Spahiu S, Jaha L. Characteristics of Rotavirus Diarrhea in Hospitalized Children in Kosovo Materia Socio Medica 2014;26:335-8.

14. Parashar UD, Nelson EAS, Kang G. Diagnosis, management, and prevention of rotavirus gastroenteritis in children. BMJ 2013;30;347:f7204.

15. Nitsch-Osuch A, Kuchar E, Kosmala A, Życinska K, Wardyn K. Nosocomial rotavirus gastroenterocolitis in a large tertiary pediatric hospital in Warsaw, 2006-2010. Arch Med Sci 2013;9:493-8.

16. Multicenter Prospective Study of the Burden of Rotavirus Acute Gastroenteritis in Europe 2004 - 2005: The Reveal Study. J Infect Dis 2007;195:S4-S16.

17. Nakanishia K, Tsugawab T, Honmaa S, Nakata S, Tatsumi M,Yoto $Y$,Tsutsumi $H$. Detection of enteric viruses in rectal swabs from children with acute gastroenteritis attending the pediatric outpatient clinics in Sapporo. Japan J Clin Virology 2009;46:94-7.

18. İnan N, Ünsur EK, Demirel A, Mamçu D, Sönmez E, Arısoy A. Akut viral gastroenterit öntanılı vakalarda rotavirus, adenovirus ve norovirus sıklığının araştırıması. Ankem Derg 2014;28:14-9.

19. Guarino A, Albano F, Ashkenazi S, Gendrel D,Hoekstra JH, Shamir R, et al. European Society for Paediatric Gastroenterology, Hepatology, and Nutrition/European Society for Paediatric Infectious Diseases evidence based guidelines for the management of acute gastroenteritis in children in Europe: executive summary. J Pediatr Gastroenterol Nutr 2008;46:619-21. 